ISSN = 1980-993X - doi:10.4136/1980-993X
www.ambi-agua.net
E-mail: ambi-agua@agro.unitau.br
Tel.: (12) 3625-4212

\title{
Evaluation of the use of Pycnoporus sanguineus fungus for phenolics and genotoxicity decay of a pharmaceutical effluent treatment
}

\author{
(http://dx.doi.org/10.4136/ambi-agua.966)
}

\author{
Renata Alberto de Morais Watanabe ${ }^{1}$;Paulo de Tarso Ferreira Sales ${ }^{1,2}$; Luiza Cintra \\ Campos $^{3}$; Telma Alves Garcia ${ }^{1}$ Marize Campos Valadares ${ }^{4}$; Fernando Schimidt ${ }^{5}$; \\ Mariângela Fontes Santiago ${ }^{1,2}$ \\ ${ }^{1}$ Department of Enzimology, Federal University of Goiás (UFG), Goiânia-GO-Brazil, \\ e-mails: rewfarm@hotmail.com, paulo@tecpam.com.br, mariangelafs@gmail.com, telma@ farmacia.ufg.br, \\ ${ }^{2}$ Programa de Pós-graduação de Engenharia do Meio Ambiente, \\ Federal University of Goiás, Goiânia-GO-Brazil, \\ ${ }^{3}$ Department of Civil, Environmental and Geomatic Engineering, \\ University College London, United Kingdom, e-mail: 1.campos@ucl.ac.uk, \\ ${ }^{4}$ Laboratório de Farmacologia e Toxicologia Celular, \\ Federal. University of Goiás (UFG), Goiânia-GO-Brazil, \\ e-mail: marizecv@farmacia.ufg.br, \\ ${ }^{5}$ Centro Federal de Educação Tecnológica de Goiás, Goiânia-GO-Brazil, \\ e-mail: schimidt99@bol.com.br
}

\begin{abstract}
If not properly and efficiently treated, wastes produced by the chemical industry can contaminate the environment. Using fungi able to degrade organic compounds (e.g. phenol) seems to be a prominent method to treat pharmaceutical wastewaters, in particular, the whiterot fungus. The aim of this work was to treat pharmaceutical effluent by the Pycnoporus sanguineus fungus. Three effluent samples were collected in a pharmaceutical industry. The production of enzymes such as laccase and manganese peroxidase was determined. Their production increased throughout the treatment with the $P$. sanguineus fungus, reaching maximum concentration of $4.48 \mathrm{U}_{\mathrm{mL}}{ }^{-1}$ (Effluent 1), $8.16 \mathrm{U} \cdot \mathrm{mL}^{-1}$ (Effluent 2), $2.8 \mathrm{U} \cdot \mathrm{mL}^{-1}$ (Effluent 3) and 0.03 Abs. $\min ^{-1}$ (Effluent 2), respectively, during 96 hours of biological treatment. Genotoxic effects of the raw and treated effluents were also investigated using the in vivo mouse bone marrow micronucleus (MN) assay. Results showed the biological treatment reduced the frequency of $\mathrm{MN}$, in a dose-dependent manner, when compared to untreated sample. The decreasing of around $20 \%$ and $45 \%$ of phenolics concentration was observed throughout the treatment, confirming that laccase production can be related to the degradation of toxic compounds present in the effluent. Therefore, the biodegradation by the $P$. sanguineus fungus seems a promising method for the mineralization of recalcitrant compounds present in pharmaceutical effluents.
\end{abstract}

Keywords: pharmaceutical effluent, biodegradation, Pycnoporus sanguineus, laccase, Manganese peroxidase.

\section{Avaliação do uso do fungo Pycnoporus sanguineus no decaimento de compostos fenólicos e genotoxicidade no tratamento de um efluente farmacêutico}

\section{RESUMO}

Se não for tratado de forma adequada e eficientemente, os resíduos produzidos pela indústria química podem contaminar o meio-ambiente. Utilizar fungos capazes de degradar compostos orgânicos (por exemplo, fenol), pode ser um método para tratar efluentes 
WATANABE, R. A. M.; SAlES, P. T. F.; CAMPOS, L. C.; GARCIA, T. A.; VALADARES, M. C.; SCHIMIDT, F.; SANTIAGO, M. F. Evaluation of the use of Pycnoporus sanguineus fungus for phenolics and genotoxicity decay of a pharmaceutical effluent treatment. Ambi-Agua, Taubaté, v. 7, n. 3, p. 41-50, 2012. (http://dx.doi.org/10.4136/ambi-agua.966)

proeminentes de insústrias farmacêuticas, em particular, os fungos da podridão branca. $\mathrm{O}$ objetivo deste trabalho foi tratar um efluente farmacêutico pelo fungo Pycnoporus sanguineus. Três amostras de efluentes foram coletadas em uma indústria farmacêutica. A produção de enzimas como a lacase e manganês peroxidase foi determinado. A sua produção durante o tratamento com o fungo $P$. sanguineus atingiu concentrações máximas de 4,48 U.mL ${ }^{-1}$ (Efluente 1), 8,16 U.mL ${ }^{-1}$ (Efluente 2), 2,8 U.mL ${ }^{-1}$ (Efluente 3) e 0,03 Abs.min ${ }^{-1}$ (efluente 2), respectivamente, durante 96 horas de tratamento biológico. Efeitos genotóxicos dos efluentes brutos e tratados também foram investigados usando o ensaio em que foi avaliada a formação de micronúcleos (MN) na medula óssea de camundongos. Os resultados mostraram que o tratamento biológico reduziu a frequência de $\mathrm{MN}$, de um modo dependente da dose, em comparação com amostras não tratadas. A diminuição de cerca de $20 \%$ e $45 \%$ da concentração de compostos fenólicos foi observada em todo o tratamento, o que confirma que a produção de lacase pode ser relacionada com a degradação de compostos tóxicos presentes no efluente. Por conseguinte, a biodegradação do fungo $P$. sanguineus parece um método promissor para a mineralização de compostos recalcitrantes presentes em efluentes farmacêuticos.

Palavras-chave: efluente farmacêutico, biodegradação, Pycnoporus sanguineus, lacase, manganês peroxidase.

\section{INTRODUCTION}

Pharmaceutical wastewaters comprise a group that, with regard to the environmental issues, has been given little attention for many years (Hirsch et al., 1999; Roberts and Thomas, 2006).

The impact of discharging pharmaceutical effluent without treatment into rivers (Chen, Wang and Ding, 2008), lakes (Boyd et al., 2004), aquifers (Godfrey, Woessner and Benotti, 2007) is quite strong, affecting both aquatic and human lives.

Phenol is one of the main toxic compounds found in pharmaceutical wastewaters and other compounds like that are called phenolics. It belongs to an aromatic organic substances family, by biological or synthetic origin. They can found as a colorless liquid or white solid at ambient temperature, and it has strong and specific odours (Kumaran and Paruchuri, 1997).

Melo et al. (2006) suggested it was necessary to evaluate the efficiency of the decontamination process, and comparing the toxicity of treated and untreated effluents. Bioassays, such as the in vivo micronucleus (MN) assay, have traditionally been used to assess the effluents toxicity, as well as monitoring the wastewater treatment (Wirzinger et al., 2007).

Using fungi able to degrade organic compounds can be a prominent method of pharmaceutical effluent treatment. In particular, the white-rot fungus has got an enzymatic system able to supporting high concentrations of toxic contaminants (Barr and Aust, 1994). These fungus have the ability of degrading recalcitrant organic pollutants such as polyaromatic hydrocarbons, chlorophenols, and polychlorinated biphenyls (Barr and Aust, 1994). This is probably due to the low specificity of their ligninolytic enzymes, such as laccase, lignin peroxidase, and manganese peroxidase (McMullan et al., 2001).

Laccase is a polyphenyloxidase able to oxidise several aromatic compounds (e.g. phenol) coupled with electron reduction of oxygen in water (Durán and Esposito, 1997).

Induced and constitutive laccases are found in many fungal species, but few works have investigated laccases produced by members of the Pycnoporus group (Pointing et al., 2000). The Pycnoporus sanguineus, a white-rot fungus and comprising the Basidiomycota, was 
WATANABE, R. A. M.; SAleS, P. T. F.; CAMPOS, L. C.; GARCIA, T. A.; VAladARES, M. C.; SCHIMIDT, F.; SANTIAGO, M. F. Evaluation of the use of Pycnoporus sanguineus fungus for phenolics and genotoxicity decay of a pharmaceutical effluent treatment. Ambi-Agua, Taubaté, v. 7, n. 3, p. 41-50, 2012. (http://dx.doi.org/10.4136/ambi-agua.966)

recognised by biodegrading some textile dyes (Pointing and Vrijmoed, 2000, Trovaslet et al., 2007) and lignosulphonates (Eugenio et al., 2008). This fungus could mineralize both Lignin (recalcitrant compound present in the lignocellulosic wood matrix) and many resistant pollutants (Durán and Esposito, 2000).

Lignin and Manganese Peroxidases are produced by the majority of white-rot fungi such as Phanerochate chrysosporium, Trametes versicolor and P. sanguineus. Lignin peroxidase catalyzes the one-electron oxidation of various aromatic compounds, with subsequent formation of aryl cation radicals, which are decomposed spontaneously by various pathways. Manganese Peroxidase catalyzes the oxidation of $\mathrm{Mn}(\mathrm{II})$ to $\mathrm{Mn}(\mathrm{III})$, which in turn can oxidize several phenolic substrates (Sayad and Ellouz, 1995). These enzymes were used to decrease phenolic and non-phenolic polluants (Rodríguez et al., 2004).

In Brazil, the country's third largest pharmaceutical and chemical pole is located in the State of Goiás. Within this context, part of the environmental contamination in Goiás is probably attributed to the pharmaceutical industry activities. This work was developed to evaluate the biological treatment of a pharmaceutical effluent by $P$. sanguineus fungi. The genotoxic effects of the raw and treated effluent were also investigated, using the in vivo mouse bone marrow MN assay. Genetic toxicology tests are assays designed to detect direct or indirect genetic damage induced by compounds.

\section{MATERIALS AND METHODS}

\subsection{Effluent}

Three samples of $20 \mathrm{~L}$ each were collected from a pharmaceutical industry in Goiás, Brazil and kept at $4^{\circ} \mathrm{C}$. The sampling technique used was the composite sampling.

\subsection{Fungus and Growth Media}

The fungus used in this work was the Pycnoporus sanguineus CCT-4518 which was provided by the Andre Tosello Foundation, São Paulo, Brazil. The fungus was incubated in potato dextrose agar (PDA) media. The Petri dishes were incubated in $37^{\circ} \mathrm{C}$ for 6 days.

\subsection{Treatment Process}

For the treatment process, it was used $100 \mathrm{ml}$ of the each effluent sample (samples 1, 2 and 3), and the growth media with the fungus. All the samples were incubated in C24KC Refrigerated Incubator Shaker (Edison NJ. USA) for 24, 48, 72, and 96 hours at $150 \mathrm{rpm}$ and $28^{\circ} \mathrm{C}$. The control sample was also treated in the same conditions (as a control, the growth media and the fungus was inoculated to the samples and after that, they were decontaminated at $121^{\circ} \mathrm{C}$ for 15 minutes). After 24, 48, 72 and 96 hours of treatment, all samples were filtered (filter papers) and they were stored in amber glass flasks at $4^{\circ} \mathrm{C}$ (adapted from Santiago, 1999).

\subsection{Total Phenolics Determination}

Phenolis concentrations were determined by the colorimetric method using FolinCiocalteu reagent (APHA, 1992). The reaction mixture was: $1000 \mu \mathrm{L}$ of effluent, $250 \mu \mathrm{L}$ of sodium carbonate solution $\left(12 \mathrm{~g} . \mathrm{L}^{-1}\right)$ and $25 \mu \mathrm{L}$ of Folin-Ciocalteau 2 mol.L ${ }^{-1}$. All samples were kept at $20^{\circ} \mathrm{C}$ for $30 \mathrm{~min}$. The phenolics concentrations were determinated at $700 \mathrm{~nm}$, in a spetrophotometer. The results were expressed in $\mathrm{mg} . \mathrm{L}^{-1}$ of phenolics, using the calibration curve in the range of 0 to $14 \mathrm{mg} . \mathrm{L}^{-1}$ which was obtained using the same procedure, using phenol as a standard. 
WATANABE, R. A. M.; SAleS, P. T. F.; CAMPOS, L. C.; GARCIA, T. A.; VAladARES, M. C.; SCHIMIDT, F.; SANTIAGO, M. F. Evaluation of the use of Pycnoporus sanguineus fungus for phenolics and genotoxicity decay of a pharmaceutical effluent treatment. Ambi-Agua, Taubaté, v. 7, n. 3, p. 41-50, 2012. (http://dx.doi.org/10.4136/ambi-agua.966)

\subsection{Determination of Laccase (Benzenediol: oxygen oxidoreductase, EC 1.10.3.2) Enzymatic Activity}

The enzymatic activities were determined in treated and untreated effluent. The control samples were used to detect likely interferences in the enzymatic methodology. The laccase enzymatic activity was determined in duplicates at $30^{\circ} \mathrm{C}$ for $3 \mathrm{~min}$ and $5 \mathrm{~min}$ using $1 \mathrm{mol.L} \mathrm{L}^{-1}$ Syringaldazine (4-hydroxy-3,5-dimethoxybenzaldehydeazine) as substrate. The reaction mixture consisted of a buffered solution of $300 \mu \mathrm{L}$ of sodium acetate 0.05 mol. $\mathrm{L}^{-1}(\mathrm{pH}=5.0)$, $600 \mu \mathrm{L}$ of filtrate (previously centrifuged at $12,000 \mathrm{rpm}$ during $15 \mathrm{~min}$ at $4^{\circ} \mathrm{C}$ ) and $100 \mu \mathrm{L}$ of Syringaldazine $1 \mathrm{~mol} . \mathrm{L}^{-1}$. The enzymatic activities were determined in $525 \mathrm{~nm}$ (absorbance). The reaction started by the addition Syringaldazine $\left(\varepsilon_{525}=6.5 \times 10^{4} \mathrm{~mol} \cdot \mathrm{L}^{-1} \cdot \mathrm{cm}^{-1}\right)$ and the enzymatic activity was measured after 3 and 5 min later. From each value found, the control value was subtracted in order to remove possible disturbances of other compounds. The arithmetic average of the absorbance values of each treatment period was calculated. One unit laccase activity was defined as the amount of enzyme causing one unit increase in absorbance per min per $\mathrm{mL}$ of the assay (adapted from Szklarz et al., 1989).

\subsection{Determination of Manganese Peroxidase (MnP, EC 1.11.1.7) Enzymatic Activity}

The activity of peroxidase dependent on Mn (II) was determined by the oxidation of red phenol. The reaction mixture $(1.0 \mathrm{~mL})$ consisted of $500 \mu \mathrm{L}$ filtrate juice, $100 \mu \mathrm{L}$ of Sodium Lactate 0.25 mol. $\mathrm{L}^{-1}, 200 \mu \mathrm{L}$ of bovine albumine $0.5 \%, 50 \mu \mathrm{L}$ of Manganese Sulphate 2.0 mmol. $\mathrm{L}^{-1}, 50 \mu \mathrm{L}$ of Hydrogen Peroxide solution 2.0 mol. $\mathrm{L}^{-1}$ prepared in Sodium Succinate buffer 0.2 mol. $\mathrm{L}^{-1}(\mathrm{pH}=4.5)$ and $100 \mu \mathrm{L}$ of red phenol $0.1 \%$. The mixture was incubated at $30^{\circ} \mathrm{C}$ for $5 \mathrm{~min}$ and the reaction was stopped by adding $40 \mu \mathrm{L}$ sodium hydroxide $2.0 \mathrm{~mol} . \mathrm{L}^{-1}$. The absorbance was set at $610 \mathrm{~nm}$ and the enzymatic activity was expressed in Abs. $\mathrm{min}^{-1}$ (Kuwahara et al., 1984).

\subsection{Determination of Lignina Peroxidase (LiP, EC 1.11.1.7) Enzymatic Activity}

Lignina peroxidase activity was determined by the oxidation of veratryl alcohol $\left(\varepsilon_{310}=\right.$ 9,300 mol. $\left.\mathrm{L}^{-1} \cdot \mathrm{cm}^{-1}\right)$. The reaction mixture $(1 \mathrm{~mL})$ consisted of $600 \mu \mathrm{L}$ of filtrate, $200 \mu \mathrm{L}$ of hydrogen peroxide, $2.0 \mathrm{mmol} . \mathrm{L}^{-1}$ and $200 \mu \mathrm{L}$ of veratryl alcohol solution $2.0 \mathrm{mmol} . \mathrm{L}^{-1}$ in sodium tartarate buffer $0.4 \mathrm{~mol} . \mathrm{L}^{-1}(\mathrm{pH}=3.0)$. The reaction was started by adding the hydrogen peroxide and the appearance of veratryl alcohol oxidized was determined by absorbance at $310 \mathrm{~nm}$ (Tien and Kirk, 1984).

\subsection{Toxicity Tests}

The in vivo genotoxicity of the raw and treated pharmaceutical effluent $(0.1 ; 0.2$ or 0.3 mL.day ${ }^{-1}$ per mouse) was investigated in mice $(n=5)$ orally exposed, for 10 days, using the bone marrow cells micronuclei assay. The experiments were carried out on adult male Swiss mice (8-12 week) obtained from the Chemical Industry of Goiás (IQUEGO). All mice weighed between $28 \mathrm{~g}$ and $30 \mathrm{~g}$ and were kept under constant environmental conditions with 12:12 light-dark cycle. All were fed standard granulated chow and given drinking water $a d$ libitum. Animal experiments were done in accordance with Institutional Protocols of Animal Care. The micronuclei frequency was performed 24 hours after the exposure.

\subsubsection{Micronucleus test}

The mutagenicity of the effluents was evaluated using the micronucleus test by scoring 1.000 bone marrow cells per each of 05 animals per treatment group, as described by MacGregor et al. (1987). The cells were stained with Leishman, the slides were coded, and the cells blindly scored by light microscope at 1000 magnification. The frequency of $\mathrm{MN}$ in 
WATANABE, R. A. M.; SAlES, P. T. F.; CAMPOS, L. C.; GARCIA, T. A.; VALADARES, M. C.; SCHIMIDT, F.; SANTIAGO, M. F. Evaluation of the use of Pycnoporus sanguineus fungus for phenolics and genotoxicity decay of a pharmaceutical effluent treatment. Ambi-Agua, Taubaté, v. 7, n. 3, p. 41-50, 2012. (http://dx.doi.org/10.4136/ambi-agua.966)

individual mice was used as the experimental unit, with variability (standard deviation) based on differences among animals within the same group.

\section{RESULTS AND DISCUSSION}

The higher laccase production was determined in 96 hours of treatment (4.48 U.mL-1, 8.16 U.mL-1 and 2.8 U.mL-1) for the effluent samples 1, 2 and 3 respectively. It was not determined laccase production in control samples, showing the relation between fungus growth and enzymatic production, as studied by Garcia (2007). Laccase production during the treatment process is shown in Figure 1.

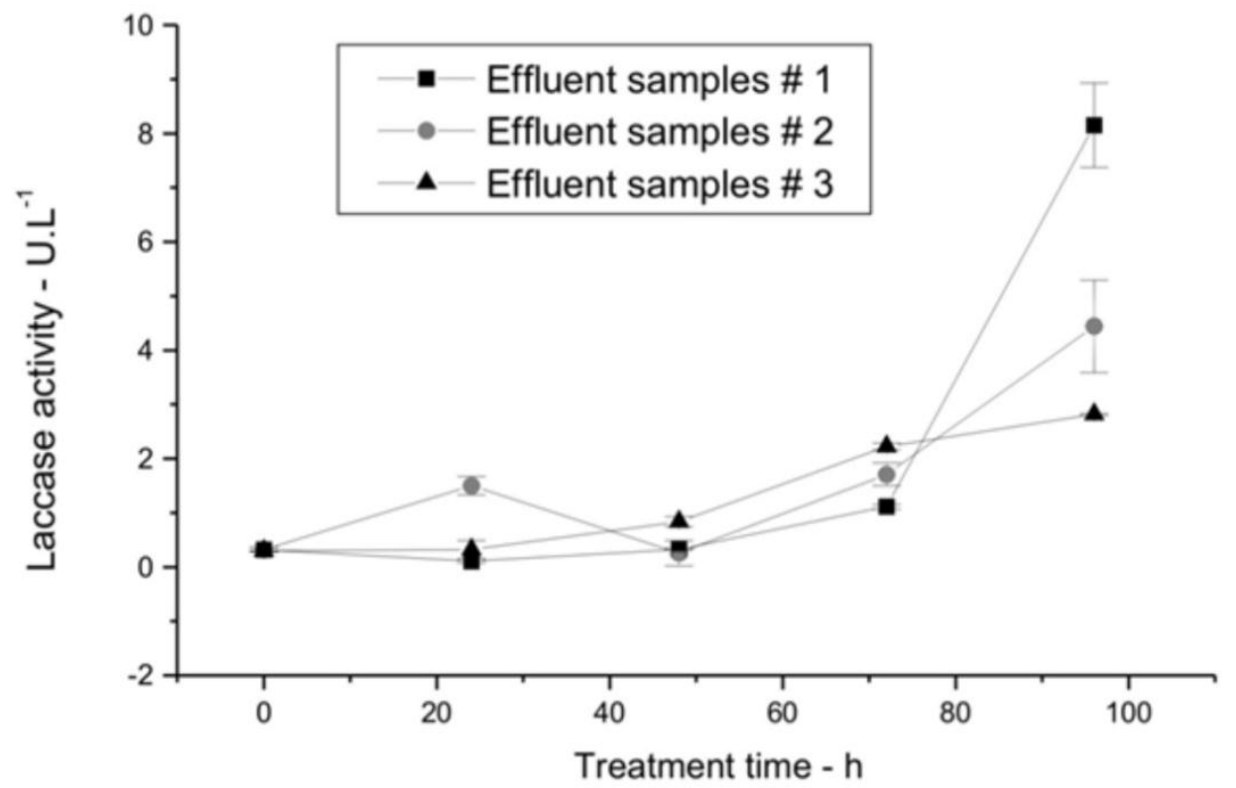

Figure 1. Laccase production for the pharmaceutical effluents 1,2 and 3 treated by Pycnoporus sanguineus.

Manganese Peroxidase enzyme production, also responsible for toxic compound degradation, by the P. sanguineus fungus was determinated in the treated effluent 2 (Figure 2), was also higher in 96 hours of treatment, equal to 0.03 ABS.min-1. The Manganese peroxidase production of was not detected in raw effluent 2 and in control samples. Studies showed the Manganese Peroxidase production is regulated by the nitrogen and carbon substrate concentration and they are inversely proportional to (Linko, 1992). Therefore, the increasing of $\mathrm{MNp}$ production towards the biological treatment indicates the decreasing of organic compounds in the effluent (not shown in Figure 2).

In the samples 1 and 3 and in their controls, the manganese peroxidase production was null. Similar results were found for the production of lignin peroxidase in the effluent samples 1, 2 and 3 treated by the P. sanguineus fungus and their control samples (not treated).

The $\mathrm{pH}$ of the samples 1 and 2 (treated effluent - Figure 3) presents a drop (i.e. acidification) between 24 and 48 hours of treatment and it increased up to its initial value ( $\mathrm{pH}$ $=5.5-6.0$ ). For the effluent 3 , the $\mathrm{pH}$ increased with time during whole treatment time (Figure 3). For the control, the $\mathrm{pH}$ was approximately constant and equal to 4.7, 6.4 and 4.6 respectively for the samples 1,2 and 3 .

According to Garcia et al. (2007), laccase tends to react differently to different substrates depending on the $\mathrm{pH}$. The purified laccase, using syringaldazine as substrate, presented optimum $\mathrm{pH}$ in acid interval (around 4.2) and the same was observed to other laccases from 
WATANABE, R. A. M.; SAlES, P. T. F.; CAMPOS, L. C.; GARCIA, T. A.; VALADARES, M. C.; SCHIMIDT, F.; SANTIAGO, M. F. Evaluation of the use of Pycnoporus sanguineus fungus for phenolics and genotoxicity decay of a pharmaceutical effluent treatment. Ambi-Agua, Taubaté, v. 7, n. 3, p. 41-50, 2012. (http://dx.doi.org/10.4136/ambi-agua.966)

other fungi. $\mathrm{pH}$ range in acid interval is within the interval of optimum $\mathrm{pH}$ for laccase, $\mathrm{MnP}$ and LiP activities (Wesenberg et al., 2003). Figure 3 shows the treatment time that all samples $\mathrm{pH}$ values were below 7.0 (acid). However, the $\mathrm{pH}$ values of all samples were between 5.0 and 6.0 at the end of treatment (at 96 hours).

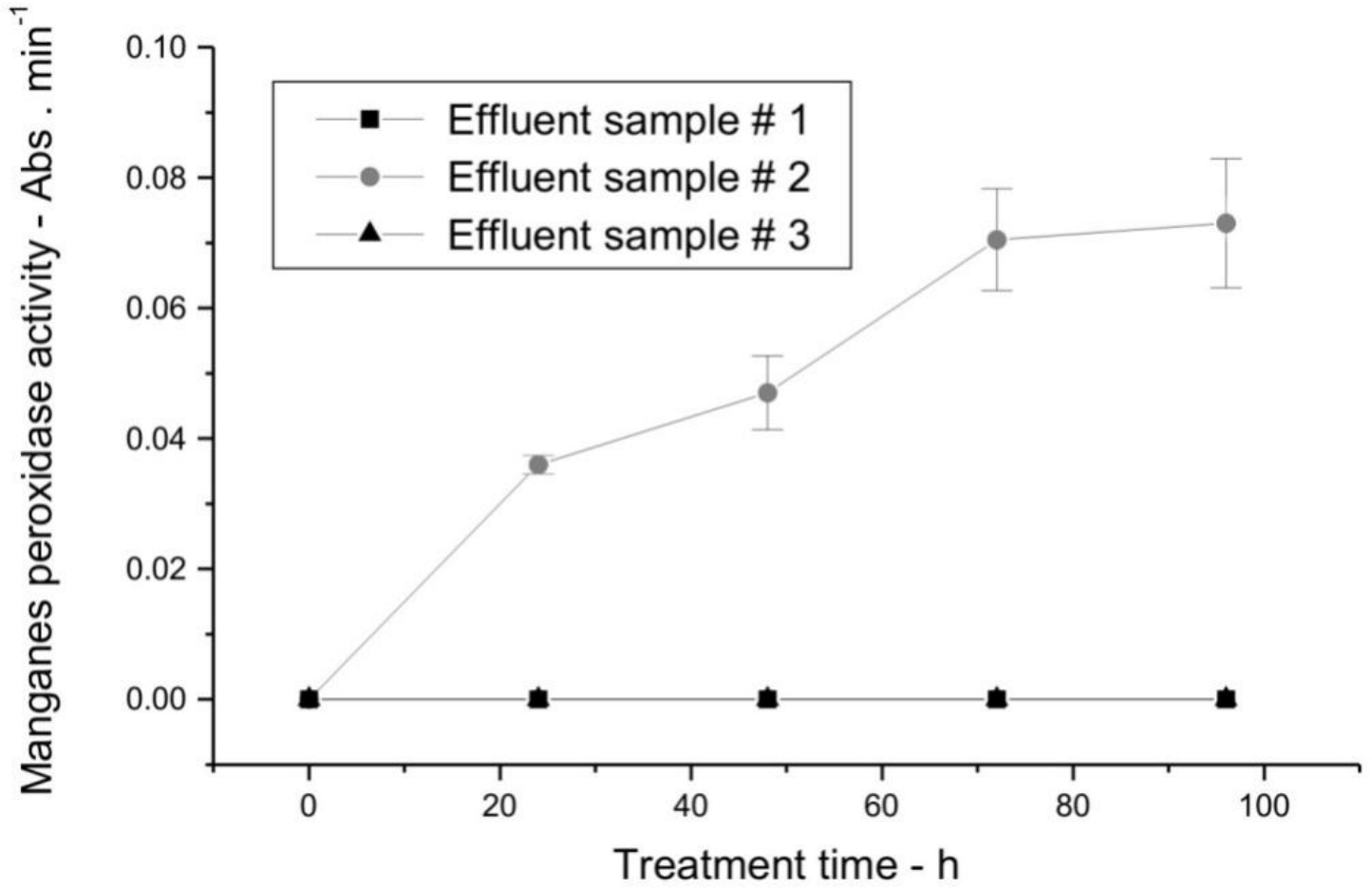

Figure 2. Manganese peroxidase production in the effluent 2 treated by the Pycnoporus sanguineus, during 96 hours.

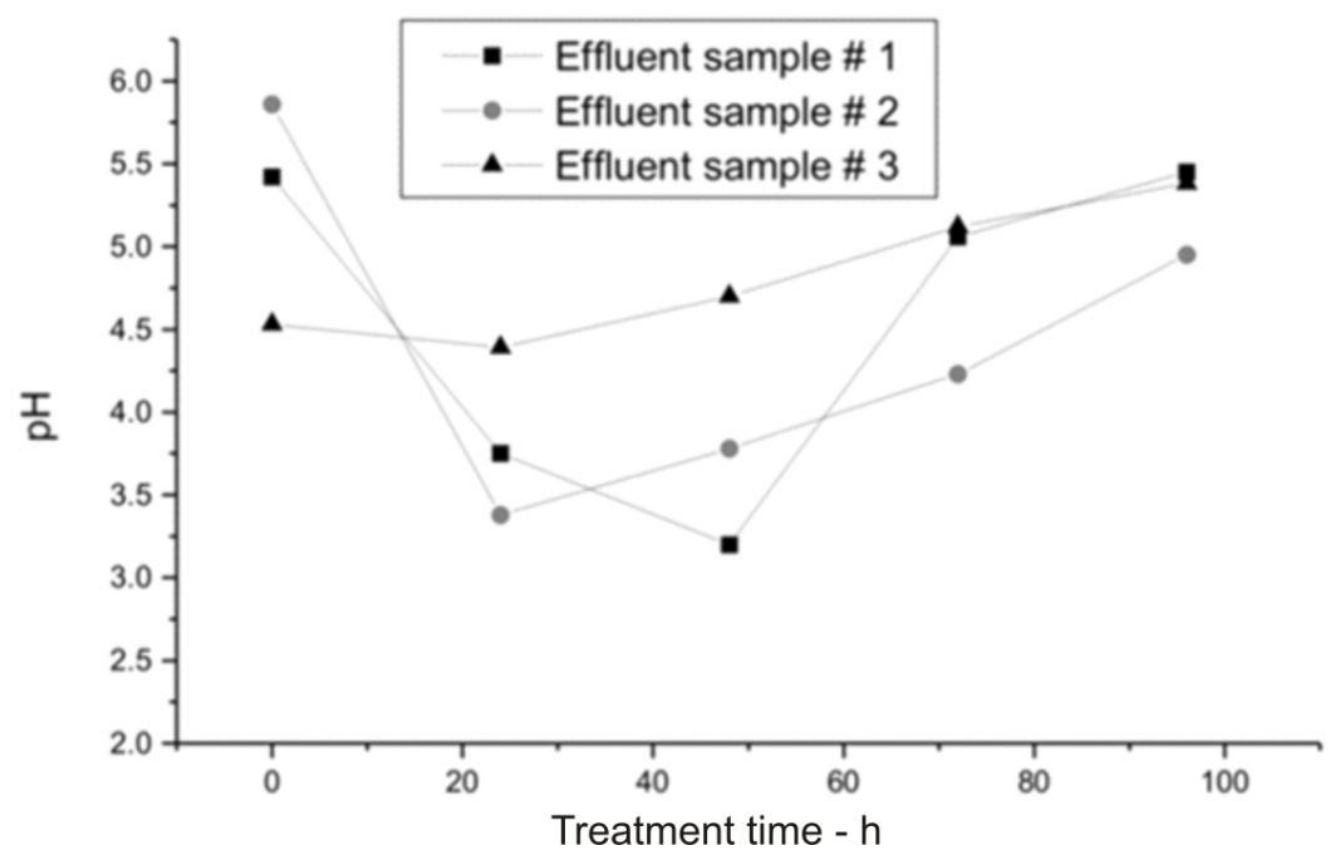

Figure 3. Variation of $\mathrm{pH}$ values during the biological treatment. 
WATANABE, R. A. M.; SAleS, P. T. F.; CAMPOS, L. C.; GARCIA, T. A.; VAladARES, M. C.; SCHIMIDT, F.; SANTIAGO, M. F. Evaluation of the use of Pycnoporus sanguineus fungus for phenolics and genotoxicity decay of a pharmaceutical effluent treatment. Ambi-Agua, Taubaté, v. 7, n. 3, p. 41-50, 2012. (http://dx.doi.org/10.4136/ambi-agua.966)

The phenolics concentration during the biological treatment can be seen in Figure 4, that shows the decreasing around $20 \%$ and $45 \%$ of all samples, comparing to untreated samples.

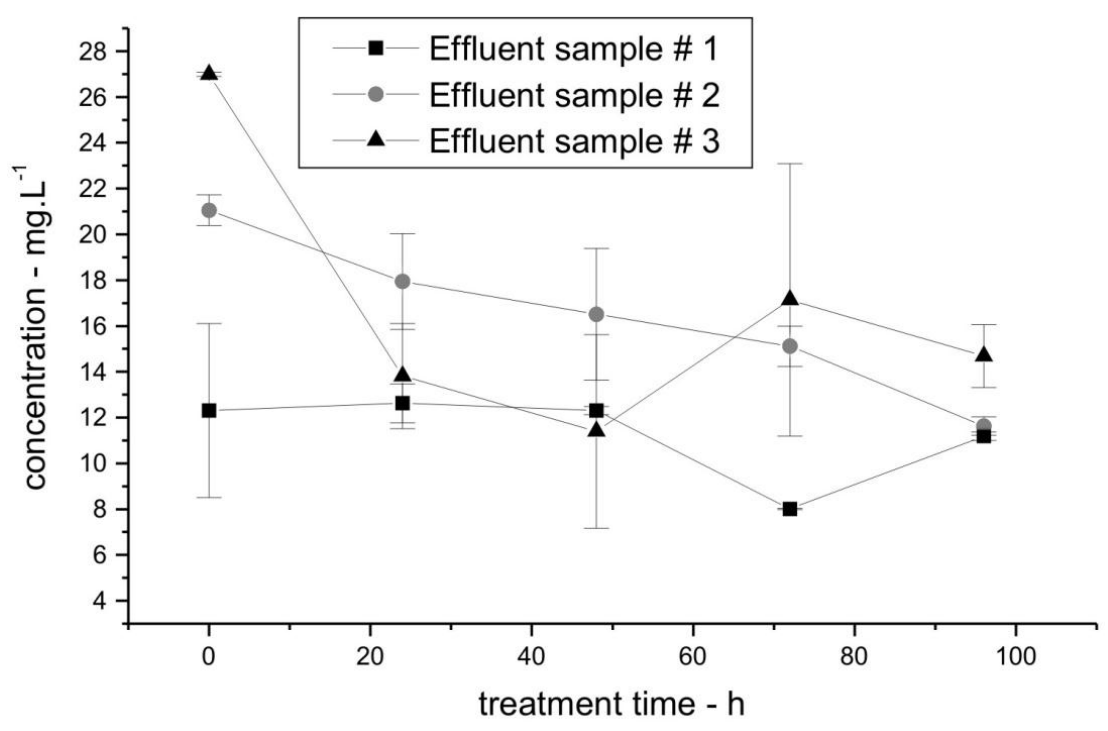

Figure 4. Phenolics concentration for the pharmaceutical effluents 1, 2 and 3 treated by the $P$. sanguineus fungus.

Comparing the enzyme production and the phenolics degradation, it was observed the Laccase and Managese Peroxidase productions increasing, as a result of decreasing of the phenolics, during the biological treatment. This result confirms Laccase production can be related to the degradation of toxic compounds into effluents. In the same way, when the in vivo genotoxicity was investigated it was observed the reduction of frequencies of micronucleated erytrocytes from mice, in a dose-dependent manner, when it was compared to untreated sample (Figure 5).

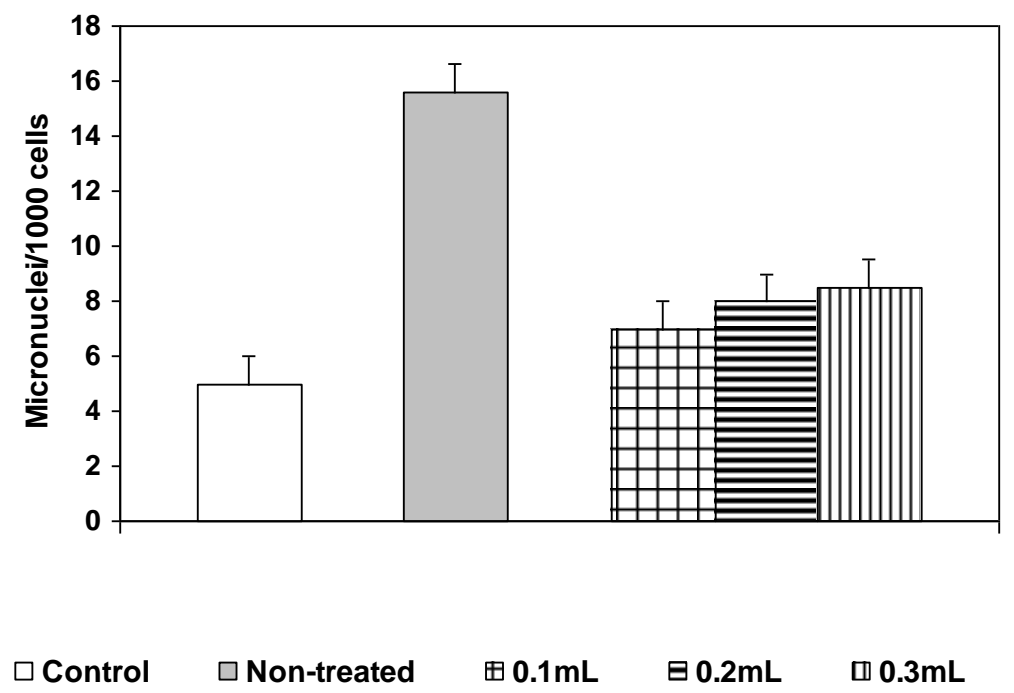

Figure 5. Effects of the raw (non-treated) and treated pharmaceutical effluent $\left(0.1 ; 0.2\right.$ and $0.3 \mathrm{~mL}^{-\mathrm{day}^{-1}}$. mouse $\left.^{1}\right)$, per oral, for 10 days on the frequencies of micronucleated erytrocytes $(\mathrm{MN})$ from mice $(\mathrm{n}=5)$. The control group received saline solution only. 
WATANABE, R. A. M.; SAlES, P. T. F.; CAMPOS, L. C.; GARCIA, T. A.; VALADARES, M. C.; SCHIMIDT, F.; SANTIAGO, M. F. Evaluation of the use of Pycnoporus sanguineus fungus for phenolics and genotoxicity decay of a pharmaceutical effluent treatment. Ambi-Agua, Taubaté, v. 7, n. 3, p. 41-50, 2012. (http://dx.doi.org/10.4136/ambi-agua.966)

Wirzinger et al. (2007) demonstrated that genotoxic assays including the MN test, can be applied routinely for the evaluation of the genotoxic potential of waters.

\section{CONCLUSIONS}

Based on the results, $P$. sanguineus fungus was able to produce high amount of laccase and small amount of manganese peroxidase enzymes for the treatment of the pharmaceutical effluent investigated in this work. The decreasing of phenolics concentration during the biological treatment showed $P$. sanguineus has a high potential of reducing the genotoxic for this kind of effluent, with a high laccase production during the biological treatment.

\section{ACKNOWLEDGEMENTS}

This work was funded by International Foundation for Science (IFS)/W3433-1, CNPQ (Conselho Nacional de Desenvolvimento Científico e Tecnológico), SECTEC-GO (Secretaria de Ciência e Tecnologia do Estado de Goiás) and Edital MCT/CNPq/CT-Hidro n 14/2005.

\section{REFERENCES}

AMERICAN PUBLIC HEALT ASSOCIATION (APHA). Standard Methods for the Examination of Water and Wastewater. 17. ed. Washington DC, USA, 1992.

BARR, D. P.; AUST, S. D. Mechanisms white rot fungi use to degrade pollutants. Environmental Science \& Technology, 28 (2), 1994, 79 - 87.

BOYD, G. R.; PALMERI J. M., ZHANG S.; GRIMM D. A. Pharmaceuticals and personal care products (PPCPs) and endocrine disrupting chemicals (EDCs) in storm water canals and Bayou St. John in New Orleans, Louisiana, USA. Science of the Total Environment, Amsterdan, 333 (1-3), 137-148, 2004.

CHEN, H.; WANG P.; DING W. Using liquid chromatography-ion trap mass spectrometry to determine pharmaceutical residues in Taiwanese rivers and wastewaters. Chemosphere, 6, 72, 863-869, 2008.

DURÁN, N.; ESPOSITO, E. 1997. Lignin biodegradation and effluent treatment by ligninolytic fungi. In: I. S. De Melo, J. L. Acevedo (Eds.). Microbiologia Ambiental, CNPMA/EMBRAPA Publishers. São Paulo, Brazil, Chapter 12, pp. 269.

DURÁN, N.; ESPOSITO, E. Potential applications of oxidative enzymes and phenoloxidaselike compounds in wastewater and soil treatment: a review. Applied Catalysis B: Environmental, 28, 2000, $83-89$.

EUGENIO, M. E.; CARBAJO, J. M.; TERRÓN, M. C.; GONZÁlEZ, A. E.; VILlAR, J. C. Bioremediation of lignosulphonates by lignin-degrading basidiomycetous fungi. Bioresources Technology, 99 (11), 2008, 4929-4934.

GARCIA, T. A.; SANTIAGO, M. F.; ULHOA, C. J. Studies on the Pycnoporus sanguineus CCT-4518 laccase purified by hydrophobic interaction chromatografy. Applied Microbiology and Biotechology, 75 (2), 2007, 311 - 318.

GODFREY, E.; WOESSNER, W. W.; BENOTTI, M. J. Pharmaceuticals in On-Site Sewage Effluent and Ground Water, Western Montana. Groundwater, 45 (3), 2007, 263-271. 
WATANABE, R. A. M.; SAlES, P. T. F.; CAMPOS, L. C.; GARCIA, T. A.; VALADARES, M. C.; SCHIMIDT, F.; SANTIAGO, M. F. Evaluation of the use of Pycnoporus sanguineus fungus for phenolics and genotoxicity decay of a pharmaceutical effluent treatment. Ambi-Agua, Taubaté, v. 7, n. 3, p. 41-50, 2012. (http://dx.doi.org/10.4136/ambi-agua.966)

HIRSCH, R.; TERNES, T.; HABERER K.; KRATZ, K. L. Occurence of antibiotics in the aquatic environment. Science of the Total Environment, Amsterdan, 225, 1999, 109118.

KUMARAN, P.; PARUCHURI, Y. L. Kinetics of phenol biotransformation. Water Resources Research, 31(1), 1997, 11-22.

KUWAHARA, M.; GLEN, J. K.; MORGAN, M. A.; GOLD, M. H. Separation and Characterization of two extracellular $\mathrm{H}_{2} \mathrm{O}_{2}$ dependent oxidases from ligninolytic Cultures of Phanerochaete chrysosporium. FBS Letters, 169, 1984, 247-250.

LINKO, S. Production of Phanerochaete chrysosporium Lignin Peroxidase. Biotechnology Advances, 10 (2), 1992, 191 -236.

MACGREGOR, J. T.; HEDDle, J. A.; HITE, M., MARGOLIN, B. H.; RAMEL, C. SALAMONE, M. F., TICE, R. R., WILD, D. Guidelines for the conduct of micronucleus assay in mammalian bone marrow erythrocytes. Mutatation Research. 189, 1987, 103-112.

MCMULLAN., G.; MEEHAN, C.; CONNEELY, A.; KIRBY, N.; ROBINSON, T.; NIGAM, P.; BANAT I.M., MARCHANT, R.; SMYTH, W. F. Microbial decolourisation and degradation of textile dyes. Applied Microbiology and Biotechology, 56, 2001, 81-87.

MELO, P. S.; FABRIN-NETO, J. B.; MORAES, S. G.; ASSALIN, R.; DURÁN, N.; HAUN, M. Comparative toxicity of effluents processed by different treatments in V79 fibroblasts and the Algae Selenastrum capricornutum. Chemosphere, Oxford, 62, 2006, 1207-1213.

POINTING, S. B.; JONES, E. B. G.; VRIJMOED, L. L. P. Optimization of laccase production by Pycnoporus sanguineus in submerged liquid culture. Mycologia, V 92, 2000, 139-144.

POINTING, S. B.; VRIJMOED L. L. P. Decolorization of azo and triphenylmethane dyes by Pycnoporus sanguineus producing laccase as the sole phenoloxidase. World Journal f. Microbiology and Biotechnology, 16, 2000, 317-318.

ROBERTS P. H., AND THOMAS K.V. The occurrence of selected pharmaceuticals in wastewater effluent and surface waters of the lower Tyne catchment. Science of the Total Environment, Amsterdan, 356 (1-3), 2006, 143-153.

RODRÍGUEZ, E.; NUERO, O.; GUILLEN, F.; MARTINEZ, A.T.; MARTINEZ, M.J.. Degradation of phenolic and non-phenolic aromatic pollutants by four Pleurotus species: The role of laccase and versatile peroxidase. Soil Biology \& Biochemistry, 36 (6), 2004, 909-916.

SANTIAGO, M. F. Estudo de substâncias de baixa massa molar que mimetizam as fenoloxidases com aplicações em tratamento de efluentes industriais. Tese de doutorado, Universidade Estadual de Campinas, São Paulo, Brazil. 1999.

SAYAD, S.; AND ELLOUZ, R. roles of lignin peroxidase and manganese peroxidase from phanerochaete chrysosporium in the decolorization of olive mill wastewaters. Applied Environmental Microbiology, 61(3), 1995, 1098-1103. 
WATANABE, R. A. M.; SAleS, P. T. F.; CAMPOS, L. C.; GARCIA, T. A.; VAladARES, M. C.; SCHIMIDT, F.; SANTIAGO, M. F. Evaluation of the use of Pycnoporus sanguineus fungus for phenolics and genotoxicity decay of a pharmaceutical effluent treatment. Ambi-Agua, Taubaté, v. 7, n. 3, p. 41-50, 2012. (http://dx.doi.org/10.4136/ambi-agua.966)

SZKLARZ, G. D.; ANTIBUS, R. K.; SINSABAUGH, R. L.; LINKINS, A. E. Production of phenoloxidases and peroxidases by wood-rotting fungi. Mycologia. 81 (2), 1989, 234240 .

TIEN, M.; KIRK, K. Lignin degrading enzyme from Phanerochaete chrysosporium: purification characterization and catalytic properties of a unique $\mathrm{H}_{2} \mathrm{O}_{2}$ requiring oxygenase. Proceedings of the National Academy of Sciences of the United States of America. 81, 1984, 2280-2284.

TROVASLET, M.; ENAUD, E.; GUIAVARC'H, Y.; CORBISIER, A. M.; VANHULLE, S. Potential of a Pycnoporus sanguineus laccase in bioremediation of wastewater and kinetic activation in the presence of an anthraquinonic acid dye. Enzyme and Microbial Technology, 41 (3), 2007, 368-376.

WESENBERG, D.; KYRIAKIDES, I.; AGATHOS, S. N. White-rot fungi and their enzymes for the treatment of industrial dye effluents. Biotechnology Advances, 22, 2003, 161187.

WIRZINGER, G.; WELTJE, L.; GERCKEN, J.; SORDYL, H. Genotoxic damage in fieldcollected three-spined sticklebacks (Gasterosteus aculeatus L.): a suitable biomonitoring tool? Mutat. Res. 30,628(1), 2007, 19-30. 